\title{
PÁlma Farkas
}

\section{THE NORTH AMERICAN VISIONS ON MIGUEL PRIMO DE RIVERA'S DICTATORSHIP}

In a former study I showed how the North American press saw the events evolving in Spain between September 1923 and March 1930, namely, during Miguel Primo de Rivera's dictatorship.

At that time, within the framework of the North American press, I concentrated on the daily news and I prepared a study based upon the articles of The New York Times, which proved that daily news being a news service does not (or should not) transmit opinion, and the newspaper mentioned above did meet this condition. It is also true, however, that based on the evidence of its articles the reader could have the impression that The New York Times did not turn against the dictator, what is more, the paper presented his regime as if it had accepted the dictator(ship) quietly or even supported it a little. ${ }^{1}$

In the present essay, I would like to present the writings of the North American press that do form an opinion and give an analysis about the events in Spain between 1923 and 1930. I will not focus on the articles of daily papers, but on the ones of weekly and/or fortnight's magazines.

For this paper the articles selected were the ones I had found and gathered during my field trip in Florida, USA in 2002 and 2003.

The magazines to be presented in this essay - in sequence of appearance are the following: The New Republic, The Outlook, and The Nation.

The available press material is far more abundant than the space allowed in this volume of studies, therefore I tried my best to line up the most illustrative articles so that we could get an accurate picture of the American journalists' opinion formed about the events unfolding in Spain as well as about their main characters.

The New Republic reveals even in its subtitle that it is a A Journal of Opinion. Nonetheless, we cannot only read evaluation in its articles, the magazine does publish numerous informative writings as well.

Whilst studying the articles, I found several among the magazines; one of the most striking was perhaps - as we are going to see in the articles quoted -, that each of the magazines listed above intended to compare both Primo de Rivera's personality and dictatorial regime to those of the Italian Mussolini while looking for parallels or pronounced contrasts.

1 Pálma FARKAS, "Primo de Rivera en la prensa norteamericana", in: Acta Hispanica, Tomus VIII, Szeged, Hungary, 81-86. 
On the grounds of the quotations presented here we shall see that there is no unambiguous answer to the question whether the two dictatorships indeed rest on analogous elements, if the two dictators' personalities are really so similar (or identical?), because the more articles we read, the more opinions we shall encounter. Regarding this, the first article of The New Republic coming to light following Primo de Rivera's takeover - in the absence of evidence - cannot take a stand on this question yet and, therefore, articulates its views very carefully:

"It is too early to say that the Spanish revolution is a repetition of the Fascist coup in Italy. Though time may show that General Rivera [...] is another Mussolini [...]",

The article itself is rather concise, and - after showing in telegraphese the Spanish situation - it ends with a slightly cynical note and tries to compare Primo to Mussolini: "Like Mussolini, he will now discover that the strong, stern man on horseback only begins his troubles when he comes down off his horse and goes to work." 3

The wars in Morocco are tightly linked to Primo de Rivera's dictatorship the North American press does not avoid giving analysis or expressing its opinion. Unfortunately, due to the narrow scope of this study, I do not have much possibility to illustrate this in a very detailed way; I would rather present the articles containing opinions related to the dictatorship itself.

However, having read such articles, in general the American press cannot be said to have thought well of the Spanish military actions at all, mostly because of the financial costs involved and human losses suffered in the war.

Perhaps, the following extract of an article can be a good proof of this:

"His economy campaign [...] is to begin in the place most embarrassing to a dictator: the army, which is so overrun by needless commanders, it costs twice as much to maintain the officers as the troops. The chief point in the Rivera policy is to get as many Moroccans murdered as possible, and in the shortest time possible." 4

In the magazine Primo de Rivera's personality meets with strong criticism and the reason for this is the way he treated Unamuno who is contemplated as "one of Spain's leading literary men" by the American press, while the furious author of the article, besides expressing his views of Primo's intellectual abilities, simply names the dictator a "swashbuckler":

"Miguel de Unamuno, is one of Spain's leading literary men, a liberal, but by no means revolutionary [...] He was so presumptuous as to criticize General Rivera in print. That swashbuckler, knowing himself unable to

\footnotetext{
${ }^{2}$ The New Republic, A Journal of Opinion, 26 September 1923, VOL. XXXVI, No. $460,111$.

${ }^{3}$ Idem.

${ }^{4}$ Ibidem, 3 October 1923. No. 461, 139.
} 
compete with Unamuno in a contest of brains, has replied by deporting him to the Canary Islands..." 5

The author's opinion about (the) dictator(s) can be clearly understood from the following lines:

"When you have the dictator's sort of mind, the only argument you can understand is your own: brute force."

As I have already mentioned, the American press is indeed interested in the events in Morocco, and often publishes lengthy, mainly reporting, sometimes analyzing articles dealing with such topics, therefore a regular reader can get continuously informed about the latest developments.

Journalists face a hard task during wartime and dictatorships, especially if we think about censorship.

The author of an article expresses his opinion and, at the same time, demonstrates the gravity of the Moroccan events:

"The recent news about events in Morocco is so serious that it scarcely matters whether it is true or not. If it is false, it is one of the fabrications by which politicians make history. If it is true, it can be no worse than that."7

The writer of the article is not optimistic as far as Spain's situation in Morocco is concerned:

"Her (=Spain, F.P.) internal situation is such that she cannot even hope by her own effort to maintain her present foothold on the cliffs above the Mediterranean. ${ }^{8}$ In any case, Spain cannot hold on to Morocco, even if Abdel-Krim were too weak to defeat her present strength [...]"

On 17 March 1926, under the title "BANDWAGON", several short statements are quoted by the magazine and one of them is related to Primo de Rivera. It contains - let us say - the first positive opinion so far:

"Doesn't scowl at all:

Primo de Rivera, to me, is one of the most remarkable characters in history. He is not what we would generally picture as a dictator, because he is always smiling...

The ex-Ambassador to Spain." 10

\footnotetext{
${ }^{5}$ The New Republic, 23 April 1924. VOL. XXXVIII. No. 490

${ }^{6}$ Idem.

7 John LANGDON-DAVIES, "The Riddle of Morocco. What are the French doing in North Africa?", in: The New Republic, 20 May 1925. VOL.XLII, 335.

${ }^{8}$ Idem.

${ }^{9}$ Ibidem, 336.

10 “The Bandwagon" in: The New Republic, 17 March 1926. VOL. XLVI.No. 589, 104. During Primo de Rivera's dictatorship three American ambassadors served in Spain: Alexander Moore from March 1923 to December 1925, he was succeeded by Ogden H. Hammond until October 1926. Between 1929 and 1933 Irwin B. Laughlin was the Ambassador of the United States delegated to Spain.
} 
Primo de Rivera's relationship to the university students, too, was full of fierce discords; the American press covers this in a fairly long article ${ }^{11}$ and criticizes the activity of Primo's government in this situation:

"In its present struggle with university students throughout Spain, the government has been equally blundering." 12

Primo - under the pretext of "reorganization" - closes universities, precisely five out of eleven - as we get to know from the article; and the author of the article adds:

"Primo de Rivera has announced that, if necessary, he will close all of the universities." 13

Carleton Beals sadly translates the meaning of the word "reorganization" for his readers:

"reorganization means that special crown committees take over the administration, expel refractory students, eliminate all doubtful professors, and abolish academic freedom entirely. In short, students are being deprived of any chance to receive a higher education." 14

The article discloses data and facts on Spanish education as well as the rate of illiteracy, then bitterly notes that

"[...] a Spanish child in Madrid who depends on the public schools for an education is worse off than most Negro children in the United States. The average illiteracy in Madrid [...] is about the same as that for Negroes in America. $" 15$

The journalist adds, however, that "this lack of education [...] cannot be blamed entirely upon the dictatorship" 16

Nevertheless, his opinion about the Spanish is rather negative:

"But it helps to explain the existence of a government as blind and backward as Primo de Rivera's in Spain, which once led the world in prowess and culture. An ignorant government is the product of an ignorant nation.",17

In the hour of Primo de Rivera's resignation in January 1930, the author of the article starts to deliberate on Spain's future, but leaves the question open:

"It remains to be seen, [...] whether General de Rivera is as completely out of power as the newspaper correspondents suggest, and also whether, as

${ }^{11}$ Carleton BEALS, “The Spanish Students Fight On”, in: The New Republic, 12 June 1929. VOL.LIX, No.758, 93.

12 Idem.

13 Ibidem, 94.

14 Idem.

15 Ibidem, 95.

${ }^{16}$ Idem.

17 Idem. 
is promised, General Berenguer's regime will be but one step [...] on the road back to constitutional government." 18

In the article the writer makes space for his - not in the least positive views on the Spanish King, according to which "King Alfonso is an old fashioned king [...], an autocrat, a man of the world, with nothing democratic or limited about his monarchy." 19

Then again we can read Primo's name right beside Mussolini's, nevertheless, this time we shall find no parallels. On the contrary:

"Primo has neither the bad nor the good points of Mussolini. Under his rule there was probably less violence than under previous Spanish governments." 20

The author of the article sees differences not only in the two dictators' personalities and regimes, but also regarding the people's attitude towards the dictators: "The attitude of Spain to its dictator has been precisely the opposite of that of Italy to hers. It has been hard to find anyone enthusiastic about him, and most people were openly hostile." 21

The article includes information on the Moroccan problem, the Catalan and Basque situation, too, but the writer finds an even more fundamental problem, that is, the one of the modernization of the country, and is pondering upon "how to get Spain, the last great medieval country, to consent to be modernized"

Regarding this question, however, the writer acknowledges some successes of the dictorship:

"Here the dictatorship has put up quite an imposing facade of achievement. There have been plans [...] for stimulating production, for developing the use of raw materials, for road-making and railway construction, while the exhibitions in Seville and Barcelona have been good advertisements in their way. 'Tourism' may well become a more important industry than heretofore.

[...] doubtless, there is scarcely any other country with claims to civilization where schemes for irrigation, railways, roads, industry [...] would take as long to mature as in Spain; but [...] Primo de Rivera can claim that at least he has tried to do these things and that the attempts have been a valuable piece of national education., 23

18 John LANGDON-DAVIES, "The Future in Spain", in: The New Republic, 12 February 1930.VOL.LXI. No. 793, 322.

${ }^{19}$ Idem.

${ }^{20}$ Ibidem, 323.

${ }^{21}$ Idem.

${ }^{22}$ Idem

${ }^{23}$ Idem. 
At the end of the article we can read the author's harsh opinion of the government and the role of the Church, which is the following:

"[...] Spain is, and has always been, a theocracy. The form of government is of little importance [...]. Spain regards herself as the only surviving fragment of the theocratic world-state of the middle ages; indeed, the middle ages are regarded as a golden age to be looked back upon with regret." 24

Keeping to the title of the article, however, the writer does provide us with a sort of answer concerning the "Future in Spain":

"It would probably have been to the ultimate advantage of the Spanish people if Primo de Rivera had remained in power." 25

Regarding Primo's successor, he thinks poorly of General Berenguer when he says:

"His real successor is likely to be either the mouthpiece of a new military clique or a survivor from the unsatisfactory political groups which preceded him. He should have fallen, not at the hands of the parties of yesterday, but at the hands of the parties of tomorrow. What are these parties? That they will be republican seems more than probable. There will be no alternative [...],26

The title of the first article of The Outlook almost predestines its content: "A Spanish Mussolini".

The reader may think the article of more than two pages will give us a picture on the presumed similarities between Primo de Rivera and Mussolini but, instead, the author of the article - as an introduction - tells us about Primo's military education as well as his merits. Then he briefly presents the problems till he reaches the dawn of 13 September 1923. Only when the journalist has finished relating the circumstances of Primo de Rivera's takeover, does he start to wonder which (political) group(s) or parties will Primo probably win:

"Spanish issues and parties are somewhat tangled. How about the separatists? Will Rivera succeed with them? Hardly. One of his first acts was to decree severe penalties on persons found engaged in republican or other separatist propaganda. [...] How about the Socialists? Will Don Primo de Rivera win them? Hardly, for he has seized the headquarters of the extremists - the Communists and Anarchists. [...] But he has good chance to win conservative Socialists, for, as he says, he also proposes to go a long way in the direction of "wide freedom of organization, distinguishing between fair-trade unionism and dishonest communism [...].",27

\footnotetext{
24 Idem.

25 Ibidem, 324.

${ }^{26}$ Idem.

${ }^{27}$ Elbert Francis BALDWIN, “A Spanish Mussolini”, in: The Outlook, 10 October 1923. VOL.135. No.6, 215
} 
Then the writer asks the same question regarding Primo's military success, and seems to find the answer himself:

"How about the soldiers? [...] Rivera faces the discontent among the military juntas, or officers' unions, ignored by him, as well as among those generals not included in the Directory. Moreover, his views as to spending more money on an unprofitable Moroccan colony, with its precarious foothold, have not made him particularly popular with the "forward party" [...] He can rely on the loyalty of much, if not most, of the army; if he could rely on the loyalty of it all, he would indeed be master of the situation." 28

Last but not least the writer wonders about the Spanish people's opinion and whether Primo will be popular with them:

"How about the people as a whole? Many of their representatives will refuse to recognize the new authority. But, in general, the people will be glad of a change towards economy and efficiency, no matter how undemocratic the change. ${ }^{29}$

The author's opinion is that "inevitably one thinks of the parallel between Spain and Italy" "30, and compares the two dictator(ship)s:

As for similarities, the writer highlights that "the movement in neither country is apparently directed against the monarch". ${ }^{31}$ Then he adds: "A paralell exists, but it is not so close as it might be" ${ }^{32}$ and he lists the differences:

1. "The Spanish character differs from the Italian. [...] The Italians outdistance the Spaniards in youthful exuberance and enthusiasm, and they have thus known how to carry Fascism to success with a rush. Mussolini's revolt was accentuated by lively demonstrations and processions [...]. The Spaniard is[...]far soberer; in comparison with the Italians his is a political apathy.

2. The background of Roman history was successfully drawn on to furnish the impressive outline of the Fascist organization.

3. Mussolini had for years carefully built up the Fascist forces, so that when the day came to march on Rome he could offer to Italy and the world an unparalelled spectacle.

4. He had imposed himself so graphically on the popular fancy that it became simply obsessed by his personality. "33

\footnotetext{
28 Idem.

${ }^{29}$ Idem.

30 Idem.

31 Idem.

${ }^{32}$ Idem.

33 Ibidem, 215-216.
} 
According to the author of the article, "Rivera lacks these advantages. [...] and yet, [...] it is not impossible that the Spanish Mussolini's triumph may even outrank that of the Italian. We shall see." ${ }^{34}$

In the article published on 28 August 1928 we can also read an evaluation of Primo de Rivera, which is at the same time another comparison with the Italian dictator, and this time - again - the author of the article seems to have found differences rather than analogy:

"de Rivera has failed where Mussolini has succeeded - in commanding support, discouraging rebellion, and shaping the Government to dictatorial ends. After six years in power he can point with pride to few of his [...] policies. The budget [...] is lopsided, foreign trade is still unsatisfctory, and the Government leans heavily on the loans of English and American bankers. " 35

Nevertheless, he finds one positive fact concerning Primo's virtues though apparently with mixed emotions. This merit of Primo's is related to suppressing illiteracy, and the author's view is (in contrast to many other journalists) that "the illiteracy rate is being steadily reduced. The premier may regard that as a promising sign. His enemies may, too.",36

The series of articles of The Outlook about Primo de Rivera is finished by an article - written and published following his death - which stands fully by the dictator, lists his merits, and - as the author of the article spent one year living in Spain - changes its own former opinion regarding both the whole country and the nation in a positive way.

The writer tells us about a sort of wall that, on the one hand, turns out to be symbolic - we shall see how -, and, on the other hand, it may as well mean the walls surrounding the "patio", or the two together... The journalist thinks that "the walls of Spain [...] have held back progress and held in medievalism, both made and unmade the late dictator, Primo de Rivera, halted in mid-career the greatest forward impulse in Spain's history [...] The walls and the patios of Spain then may be taken as a symbol of the baffling character and inner life of the Spanish people. Centuries of intense seclusion and exclusion have inbred a sensitive self-sufficiency and over-developed individualism that abhors outside contacts of whatsoever character.

Each patio unit is organic and quite content with and within itself. ${ }^{, 37}$ In his opinion, "the ultimate defeat of Primo de Rivera may be laid at the door of this national characteristic., 38

\footnotetext{
34 Idem.

35 “Spain's dictatorship", in: The Outlook, 28 August 1928., VOL. 152. No. 18, 695.

${ }^{36}$ Idem.

37 Henry Albert PHILLIPS „Spain is not like that”, in: The Outlook and Independent, 9 August 1930. VOL.154. No. 15, 568.

38 Idem.
} 
The author compares the Spanish and the Americans as individualistic characters, and comes to the conclusion that "the Spaniard is individualistic in a radically different manner from our inidvidualistic American. [...] We are responsive children of organized effort; unimaginative agents of mass production and organization." 39

The writer continues describing his views regarding the Spanish individualism and the people's indifference, and strongly criticizes the nation pointing out on the reason for the lack of progress or a successful uprising, he thinks that "this individual and collective indifference to the common cause is the besetting sign of Spain where progress is concerned; and its negative virtue lies in their failure to be diverted or to 'get together' in sufficient numbers to support a revolution."

The writer then mentions a feature of the Spanish which can also be taken as criticism and which can be read in other journalists's articles too:

"[...] the people are forever gazing backward toward a brilliant past of the day before yesterday, instead of reasoning and working toward an even fairer tomorrow." 41

In what follows the writer assumes that "this national trait is not confined to their relations with foreigners" and the Spanish people's "indifference at the Queen-Mother's funeral and then in the presence of King Alfonso" draws the journalist's attention - as he puts it:

"Their indifference at the funeral of the Queen mother - whom they are supposed to have loved beyond any one else in Spain - was almost ludicruous. Their indifference in the presence of King Alfonso was only a shade less so." 42 Then after having written some cynical words about the Spaniards he notices that "they are by no means a criminal people, for I never saw a public act of violence during my year in Spain" 33 but then again adds ironically that "although they will deliberately disobey the Americanized traffic regulations and argue with a policeman." 44

Before listing Primo's merits, the author expresses his bitter opinion according to which "such a race is incapable of a headlong or simultaneous revolution, and is reasonably safe for despotism or dictatorship. The walls of tradition and indifference and their deep-rooted individualism made progress or well-organized effort well-nigh impossible. For centuries, while decaying, Spain glorified in this stagnant self-hypnotism. ",45

\footnotetext{
${ }^{39}$ Idem.

40 Ibidem, 569.

${ }^{41}$ Idem.

42 Idem.

${ }^{43}$ Idem.

${ }^{44}$ Idem.

${ }^{45}$ Idem.
} 
From this point onwards the author starts to describe Primo de Rivera whom he considers "a man of energy and force" lot, and extols Primo de Rivera's virtues in the following way:

"In July, 1923, when Spain seemed about to topple over into the abyss of its own hollow visions, a truly great Spaniard, a man of energy and force, of imagination as well as vision to carry it out, and a product of French military efficiency - one Don Miguel, Marquess de Estella, then governor of Barcelona, rose up and seized the nation [...] He set about what has now proved an almost hopeless task, of transforming [...] vanity of a race of individuals in their past into a progressive and united nation intent to its future." $" 77$

As for people's acceptance of the Spanish dictator the writer thinks that "there seemed little doubt that de Rivera was their acknowledged national leader; but obviously they did not hail him as their national hero as well." 48

Phillips is also among the journalists who will not avoid mentioning the names of Primo de Rivera and Mussolini on the same page:

"Rivera had none of the Mussolini bearing or overbearing; rather he was almost gracious in his manner." 49

Regarding Primo's takeover and "lust for power" the writer sides with the Spanish dictator and states:

"It is a mistaken idea to suppose that General Primo de Rivera seized the Spanish government in a mere lust for power. Rivera was primarily a reformer, a modern Cervantes, whose single touch of romance was a dream to put Spain back on the map of Europe by modern means. "50

The writer praises Primo's work and his actions planned for the sake of the nation as follows:

"His desire was to save his native land from [...] bankruptcy and disintegration and put her on a sound business footing. To break down the walls of the Moorish and medieval patios that began at the Pyrenees!" 51

The journalist points out three problems in which - according to his opinion - Primo de Rivera held his ground:

1. Morocco. As for this question the writer's view is brief:

"[...] at a terrible cost perhaps, de Rivera settled the Moroccan-Rif question" $" 52$

\footnotetext{
${ }^{46}$ Idem.

${ }^{47}$ Idem.

${ }^{48}$ Idem.

${ }^{49}$ Idem.

${ }^{50}$ Ibidem, 569-570.

${ }^{51}$ Idem.

${ }^{52}$ Idem.
} 
2. The problem of the separatist movement.

"Catalonia was on the verge of revolution and secession...Rivera not only put them down but turned the warped energies of all in the direction of a united Spain." 53

3. Graft.

The journalist will not leave the problem of the army untouched either and assumes that "the Army was perpetually plotting against him, because they felt that he had betrayed them by cutting out the opportunity for further Army graft [...] ",54

He believes that "Dictator de Rivera was mistakenly likened to Mussolini",55 and we can read that he thinks "the two men and their methods were diametrically opposite. De Rivera was a lonely pine, with everything and everybody [...] against him. He had little of the personal magnetism and inspirational qualities that have played so large a part in Mussolini's success.

He made no attempt to rouse the ancient spirit and pride of his people through their imagination, knowing his people's failings in this direction too well and that it would be fatal to progress. "56

About the Spanish nation he states with noble simplicity that "there is little doubt but that Spain admired de Rivera and the more intelligent grievously miss him today". 57

Regarding the relation between Primo de Rivera and the Church, the author has the impression that "the Church distrusted de Rivera, the nobles envied him and forced the King to go record officially as his enemy"58, "although - he adds - I am of the opinion that privately the King thanked him [...] for all he had done for Spain and personally dreaded to have him resign",59.

As far as the fights of political powers are concerned, about which the writer believes that "the Dictator had put down and held down so effectually", he makes the following notes:

"Now, with Rivera dead, these factions are unleashed to tear each other to pieces. The Communists and the Separatists, the Socialists and the Anarchists, the Monarchists and the Militarists, whom the dictator had put down and held down so effectually, are slowly rising and recreating the old chaos. ",60

As far as Primo's failure, the journalist declares:

\footnotetext{
53 Idem.

${ }^{54}$ Idem.

55 Idem.

${ }^{56}$ Idem.

57 Idem.

58 Idem.

${ }^{59}$ Idem.

${ }^{60}$ Ibidem, 570,; 598
} 
"Primo de Rivera did not fail; rather, Spain failed him"61

He does not have in the least a high opinion of Primo's successor, the Berenguer government:

"The newly established government of General D'Amaso Berenguer has little more significance than a political emergency or breathing spell.",62

The third magazine I have surveyed is The Nation.

In the first article published only a fortnight after Primo's takeover, the writer does not spare the Spanish government when expresses his views:

"[...] the government of Spain is the most autocratic in Europe, if we are willing to except the temporary dictatorships in Russia and Italy",63

Nevertheless, he does not have a poor opinion of the Spanish:

"The Spaniard as an individual is the most democratic of persons [...]"

The writer does not portray the King as the best monarch in the world, on the contrary:

"In twentieth-century Spain the King still rules by divine right [...]. Buttressed by grandees, life senators, army officers, and high ecclesiastics, Alfonso is nevertheless a prisoner of the political system. Without their support he would lose his job and without his support they would lose their privileges. [...] It is the general belief outside Spain that Alfonso is a popular king. That is not true; he fears for his life like the former Czar of Russia [...] his position is extremely insecure..." 65

As for the Moroccan news he states that "[...] reports about Spanish military operations in Morocco [...] mean little or nothing to us. The Spanish papers headline the Moroccan war news which is so heavily censored that it takes several days for the truth to leak out. As soon as the public realizes one reverse, another has taken place. "66

In april 1924, an article of indignant tone came out narrating Unamuno's exile and the writer of the article - which is actually an appeal as well condemns Primo's behaviour towards Unamuno.

At the end of the article the journalist asks everyone to help the broken literary man:

"Professor Unamuno was a poor man and as the Government refused to pay the price of his ticket to the Canaries, he is now in a very precarious position. I would suggest that The Nation undertake to administer such funds

\footnotetext{
${ }^{61}$ Ibidem, 598

${ }^{62}$ Idem.

63 Samuel M. WAXMAN, “The Revolt in Spain", in: The Nation, 26 September 1923. VOL.117. No.3038, 322.

${ }^{64}$ Idem.

${ }^{65}$ Idem.

${ }^{66}$ Ibidem, 323.
} 
as we may be able to collect for Unamuno. A few dollars go a long way when translated into pesetas. $" 67$

In 1929, an article analyzing the first five years of Primo's dictatorship is published. Remembering the circumstances of 1923, the author of the article gives a positive evaluation on the general's achievements:

"The five and a half years since then have [...] demonstrated that the great Primo de Rivera was safe. He has ruled the country with the forms of absolutism, yet with the tacit backing of two estates - nobility and clergy and without any real popularity. [...] The five and a half years have witnessed significant advances in the governance of Spain. ${ }^{, 68}$

Then the journalist lists all the fields where the above mentioned "significant advances" ${ }^{69}$ have taken place: "sanitation [...], railroads and other industries of the country [...], an absurdly large army of government employees has been reduded [...], as in the civil service, so in the army and navy Primo de Rivera has made astonishing reforms, [...], foreign trade has been encouraged. [...] In respect to foreign affairs, the dictatorship has consolidated the position of Spain in a satisfactory way [...]. ",70

As soon as the author gets to the end of the list he points out to the things that - as he puts it - Primo's regime "has not done" "

"it has not produced an Utopian condition of universal education literacy is as ever calculated at an appalingly low figure. It has not made any appreciable effort to develop agricultural reforms. And the most important of all [...], it has not developed any party or organization to maintain and perpetuate the regime established in 1923. "72

The author views the King and the dictator's relation as an involuntary symbiosis and he thinks that "the King and the Jefe have [...] been mutually suspicious of each other, principally because neither could last [...] without the other." $" 73$

The writer finishes the article with the thought of overthrowing the dictatorship and his opinion is that

"if the dictatorship is overthrown and replaced by a liberal government, the chaos of 1923 will probably return.

67 Hendrik Willem VAN LOON, "For Unamuno", in: The Nation, 16 April 1924.VOL. 118. No.3067, 429.

68 William H. HESSLER, “The crisis in Spain”, in: The Nation, 29 May 1929. VOL.CXXVIII. No.3334, 657.

69 Idem.

70 Idem.

${ }^{71}$ Idem.

72 Idem.

${ }^{73}$ Ibidem, 658. 
If the present Government is permitted to set up its own "constitutional regime", then a dictatorship will continue, more efficient than parlamentarism, yet hardly tending in the direction of a better life for Spain's toiling millions. ${ }^{, 74}$

This evaluation of a quite peaceful tone is followed by sharp criticism:

"Primo, with his absurd concessions, iron-clad national monopolies to benefit favorites of the regime, represents neither a laissez-faire policy nor a theory of social control, but purely a medieval economy. Primo de Rivera is an anachronism because Spain is an anachronism. His opera-bouffe enterprise in one result of Spanish stubbornness to relinquish feudal glories; of the failure to create a public school system; of the national exhaustion and political corruption which today are Spain's chief heritages from her once vast colonial empire. Indeed, Primo represents a final vain effort to shout out the modern world of Spain. [...] Primo de Rivera[...] is the culmination of Spain's colonial disasters. Primo is a direct product of the costly Moroccan stupidity",75

As a summary, we may say that the American press pays attention to the European events, and - especially in the present case - to those of Spain.

Each of the magazines mentioned in this study can be admitted to have published detailed accounts and analysis within one or two weeks after Primo de Rivera's takeover on 13 September 1923; some writings in mild tones, others in stronger ones - expressing both positive and negative opinions.

There is one more common characteristic in these magazines: none of them intended to avoid comparing Primo de Rivera's regime and personality to those of Mussolini. We can perhaps find a sort of divergence among the articles, since there is no united stand on the judgement, and almost the same number of journalists believe that Primo de Rivera is indeed a new/another Mussolini as those who are averse to accepting this possibility by saying there is nothing common in the two dictators.

The weak points of the Spanish regime attract the attention of the magazines; and the articles relate the same problems. The writings do not only state opinions, but, at the same time, they do report, and provide us with background information as well. Therefore, we can say that the North American reader could get a rich and colourful picture of the contemporary Spain of the time.

As for the Moroccan events, the opinion is unified: none of the magazines agrees with the campaigns, and their reasonings are the same: Spain is not able to keep her colonies, she is not as strong power as she used to be; the war

\footnotetext{
74 Idem.

75 Carleton BEALS, "Modern Spain.I. The Wreck of an Empire", in: The Nation. 26 June 1929. VOL. 128. Num.3338.
} 
only deepens the country's problems as it consumes dreadful sums of money, and the human loss is also striking. All these together only raise discontent.

There is, however, no firm agreement on Primo's personality, military successes and/or failures; we can read examples of both extremely condemning views and strongly supporting ones as well.

Nonetheless, there seem to be more articles thinking highly of Primo de Rivera's achievements, acknowledging the dictator's intentions of modernization. Without doubt, the interpretation - according to which Primo de Rivera's regime was a dicatorship of modernization - is acceptable. 